\section{Baby milk company fined for advertising direct to consumers}

Claire Laurent Banbury

SMA Nutrition, part of Wyeth, one of the world's biggest manufacturers of infant formula milk, was last week fined a total of $£ 26000$ (\$41 900; €37 200) and ordered to pay costs of more than $£ 34000$ after being convicted of six separate breaches of illegal advertising direct to consumers.

In what is thought to be the first case of its kind, the company was prosecuted by Birmingham Trading Standards at Birmingham Magistrates Court. Judge Rod Ross described the company's breaches as "cynical and deliberate."

A mother in Birmingham drew the Trading Standards' attention to the advertisement in Prima Baby magazine in July 2001. Further investigation found that the piece had been published five times in other magazines (Practical Parenting's Complete Guide to Pregnancy (July and September), Mother and Baby, Pregnancy (the essential guide from Newbaby), and Healthy Happy Pregnancy.

The Infant Formula and Follow On Formula Regulations 1995 and the Food Safety Act state that advertisements for infant formula for babies up to 6 months can be published or displayed only through the healthcare system, in a scientific publication, in a publication not widely available to the public, or for the purposes of trade before retail.

During the eight day trial the court heard how the company had placed an article six times in parenting magazines in 2001. Headed "advertisement," it highlighted four ingredients that parents should look out for in an infant formula.

SMA Nutrition argued that the article was not an advertisement but an information piece, which is allowed by law providing the reader is not directed to a particular product. However, the only formula at that time that contained all those ingredients was SMA Gold. The advertisement also directed people to its helpline providing direct access between company employees and parents, which is forbidden under UK legislation.

The company argued that it had done all it could to avoid committing an offence. But, in his concluding statement, Judge Ross said it had "blatantly disregarded the advice of its own legal department" that the article might be regarded as an advertisement.

Professor Alan Lucas, an honorary consultant at Great Ormond Street Hospital for
Children, called by the defence, said he found the SMA article "unexceptional" and that GPs and primary healthcare workers have a "poor understanding of infant feeding issues" and that "first time mothers often receive advice from the written media."

However, Judge Ross said the company had "deliberately crossed the line to advertise to a vulnerable section of the public." Nor did he accept the company's argument that the regulations as applied in this case restricted free movement of goods within the European Union.

The outcome was welcomed by breastfeeding organisations and pressure groups. Mike Brady, campaigns and networking coordinator of Baby Milk Action, said, 'It's a stunning victory for infants and mothers in this country, which I believe sets an important precedent and a warning to other companies with similar advertisements."

SMA Nutrition is considering whether to appeal.

\section{Drug company employee who queried trial wins appeal}

Tony Sheldon Utrecht

A former medical research manager in a drug company has won his appeal against a claim for damages awarded against him after he took his concerns about the doses of a drug in a trial to medical ethics committees without informing his employers.

Dr Koos Stiekema had been found guilty of breaching obligations of confidentiality to the Dutch pharmaceutical giant Organon, causing the company "considerable financial disadvantage.” But the Amsterdam appeal court has ruled that Dr Stiekema faced a "conflict of duties" in which he was correct to "to give preference to the interests of patients above that of Organon" and that breaches of his confidentiality obligations "were justified by a higher interest."

The court also ruled that damages should not have been awarded against him, because by confidentially informing the medical ethics committees he was not reckless and had not intended to damage the company.

The judgment is seen as offering a "guideline" in disputes between doctors who work in the drug industry and their employers. Damages are only liable if an employee deliberately damages his employer. Dr Stiekema left Organon in 1999 after a dispute over the design of the pentasaccharide in unstable angina (PENTUA) study into the efficacy of pentasaccharide, a new anticoagulant, in preventing heart attacks or death in patients with severe unstable angina (BMJ 2002;324:1240)

His "stepwise" design proposed a first phase in which doses of $12 \mathrm{mg}, 8 \mathrm{mg}$, and $4 \mathrm{mg}$ were given. In the second phase a dose lower than $4 \mathrm{mg}$ would be given, provided that the $4 \mathrm{mg}$ dose in the first phase had proved effective. Data available at the time led Dr Stiekema to conclude that doses of less than $4 \mathrm{mg}$ were unlikely to be effective. However, other experts advised Organon that it was responsible to include a dose of $2.5 \mathrm{mg}$ from the outset.

Attempts at arbitration failed, and without informing Organon Dr Stiekema took his concerns to independent European medical ethics committees overseeing the study. The PENTUA studies went ahead, and the results were pub- lished at a congress in the United States in 2001. There had been no excess deaths, and researchers concluded it had been correct to include the lower dose of $2.5 \mathrm{mg}$.

Dr Stiekema's actions, however, led to a claim against him for a three month delay to the PENTUA study, estimated at costing more than $€ 0.9 \mathrm{~m}$ (£0.6m; \$1m). Organon argued

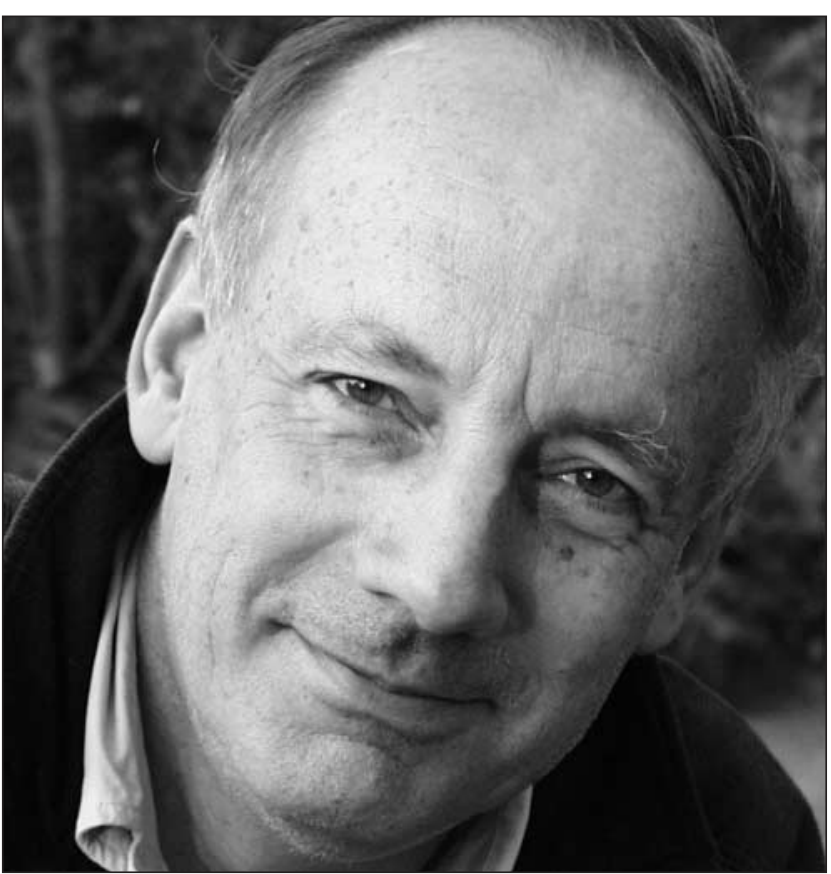

Dr Koos Stiekema has won an appeal over damages that none of the independent national and international experts on the steering group with final responsibility for the trial shared Dr Stiekema's concerns and that he had broken his obligations to confidentiality in his contract of employment. Organon is considering an appeal to the Supreme Court. 